\title{
VISUAL REACTION TIME IN PEOPLE WITH AND WITHOUT DIABETES - A COMPARATIVE STUDY
}

\author{
Pramanik $T^{1}$, Dhakal $R^{2}$, Pandit $R^{1}$
}

${ }^{1}$ Department of Physiology, Nepal Medical College, Attarkhel, Gokarneshwor-8, ${ }^{2}$ Shankarapur Hospital, Jorpati, Gokarneshwor-6, Kathmandu, Nepal

\begin{abstract}
Peripheral neuropathy is a common complication of type 2 diabetes in patients with poor diabetic control where reaction time increases in comparison to normal individual. Early detection of neural dysfunction denoted by increased reaction time will be helpful for the patient, to control blood sugar in order to avoid diabetic complications. This study was conducted to find out the neural deficit in diabetes by comparing the visual reaction time using ruler drop method between non-diabetics and diabetics and assessing the relationship of reaction time with increase in glycated hemoglobin $\left(\mathrm{HbA}_{1 \mathrm{c}}\right)$ titre. It was a case control study among 38 diabetics and 31 healthy volunteers. Among the volunteers of age groups 20-39 years and 40-59 years, all patients with poor diabetic control showed significantly high reaction time in comparison to their non-diabetic counterparts ( $180.66 \mathrm{~ms}$ vs $231.11 \mathrm{~ms} ; 197.27 \mathrm{~ms}$ vs $224.44 \mathrm{~ms}$ respectively). In age groups of 60-79 years, reaction time was also more in patients with high $\mathrm{HbA}_{1 \mathrm{c}}$ in comparison to their non-diabetic counterparts (224.00 ms vs $230.90 \mathrm{~ms}$ ). In comparison to non-diabetics, diabetics with increased $\mathrm{HbA}_{1 \mathrm{C}}$ (79\%, 9-11\%, 11-13\%, >13\%) all showed significantly higher reaction time (193.54 ms vs $219.00 \mathrm{~ms} ; 193.54 \mathrm{~ms}$ vs $225.83 \mathrm{~ms}$; $193.54 \mathrm{~ms}$ vs $236.66 \mathrm{~ms}$ and $193.54 \mathrm{~ms}$ vs more than $250 \mathrm{~ms}$ respectively). A positive Pearson Correlation $(r=0.4)$ was also noted between $\mathrm{HbA}_{1 \mathrm{C}}(\%)$ and reaction time $(\mathrm{ms})$ amongst the patients with poor diabetic control. Damage of vasa nervosum and formation and accumulation of sorbitol and fructose in Schwann cells might disrupt structure and function of peripheral nerves leading to neuropathy and altered visual reaction time in diabetics.
\end{abstract}

\section{KEYWORDS}

Visual reaction time, ruler drop method, glycated hemoglobin $\left(\mathrm{HbA}_{1 \mathrm{C}}\right)$, type 2 diabetes mellitus

\section{CORRESPONDING AUTHOR}

Prof. Dr. Tapas Pramanik

Department of Physiology,

Nepal Medical College Teaching Hospital,

Attarkhel, Gokarneshwor-8, Kathmandu, Nepal.

Email: drpramanik@hotmail.com 


\section{INTRODUCTION}

Type 2 diabetes mellitus is a global health problem and the incidence is increasing in an alarming rate. ${ }^{1}$ Diabetic peripheral neuropathy is a common complication of type 2 diabetes mellitus. ${ }^{2}$ The prevalence of diabetic neuropathy in Nepal is $58.70 \%$ as reported by Karki et al. ${ }^{3}$ The prevalence of diabetic peripheral neuropathy was noted more among the white Caucasians compared to South Indians $(54.3 \%$ vs $38.1 \%){ }^{4}$ The most common peripheral neuropathy in diabetes mellitus was distal polyneuropathy; the frequency of which increased with the duration of diabetes mellitus in patients with poor control. ${ }^{5}$

In neuropathy, reaction time increases in comparison to normal individual. ${ }^{6}$ Reaction time is the time taken from the application of a stimulus to the resulting reaction i.e. motor response. Early detection of neural dysfunction shown by increased reaction time will be helpful for the patient, to control blood sugar in order to avoid diabetic complications.

Previous studies have shown that people who had neuropathies as complication of diabetes, the $\mathrm{HbA}_{1 \mathrm{C}}$ values were above 7 . Some studies noted mostly sensory deficits in diabetics. ${ }^{3}$ Till date, to the best of our knowledge, the knowledge of the motor and the reflex deficits in diabetics is scanty. Therefore, this study was conducted to observe the diabetic's neural deficit, through the visual reaction time and relate it to $\mathrm{HbA}_{1 \mathrm{C}}$ level, by comparing the visual reaction time between non-diabetics and diabetics and assessing the relationship of reaction time with glycated hemoglobin $\left(\mathrm{HbA}_{1 \mathrm{c}}\right)$ titre.

\section{MATERIALS AND METHODS}

This was a case control study conducted between November 2017 to February 2019. Cases of diabetics who were under hypoglycemic drug therapy for at least five years $(n=38)$ were considered. Age/ sex matched normal/healthy persons served as controls $(n=31)$. Primary screening for blood sugar and evaluation of visual reaction time were conducted in the Dept of Physiology, Nepal Medical College and $\mathrm{HbA}_{1 \mathrm{C}}$ was measured in Pathology Lab, Shankharapur Hospital.

Blood sugar levels of all the volunteers were assessed. People with random blood sugar greater than $200 \mathrm{mg} / \mathrm{dL}$ were considered as diabetics. ${ }^{7}$ $\mathrm{HbA}_{1 \mathrm{C}}$ of the volunteers were recorded that reflected average glycemic control over the period of 2-3 months. ${ }^{8} \mathrm{HbA}_{1 \mathrm{C}}$ more than 7 denoted poor diabetic control; value within 7 , denoted patient with good glycemic control. If two $\mathrm{HbA}_{1 \mathrm{C}}$ reading in the gap of 3 months duration is more than 7 consecutively, diabetic control is considered as poor. ${ }^{8}$ Visual reaction time between the diabetics and normal (non-diabetic) population, as well as patients with controlled and uncontrolled diabetes mellitus was compared. Persons who were on hypoglycemic drug but with poorly controlled diabetes $\left(\mathrm{HbA}_{1 \mathrm{C}}\right.$ more than 7) since diagnosis for at least 6 months was considered. Patients with history of urinary tract infection, neuropathy other than from diabetes mellitus e.g., patients with motor neuron disease (multiple sclerosis, syringomylia) and other nervous system disease or any other infective disease, renal disease, dehydration and with impaired vision were excluded from this study.

Verbal consent of the patients were taken before the test. Research ethics was followed as per the guideline of Nepal Health Research Council and the ethical approval was taken from Nepal Medical College Institutional Review Committee before the starting of research. Participants were informed about the test, its procedure and the rationale of it. Patients willing to participate were enrolled for this study. Visual reaction time was evaluated.

Results were compared and analyzed statistically by using student's t test. ${ }^{9}$ The Pearson correlation between the high $\mathrm{HbA}_{1 \mathrm{C}}(\%)$ and reaction time in milliseconds in patients with poor diabetic control was calculated.

\section{Experimental protocol of visual reaction time by ruler drop method ${ }^{10}$}

Visual reaction time is the time taken by the brain to translate visual information (falling ruler) into voluntary (or conscious) motor commands and actions (grasping finger movements) that lead to the ruler being caught. Shorter the time, the faster is the reactions. The distance the ruler travelled from starting was recorded. Distance was converted into time by using the formulae $t=(2 d / g)^{1 / 2}$ [where, $t=$ reaction time, $\mathrm{d}=$ distance travelled by the ruler, $\mathrm{g}=9.81 \mathrm{~m} / \mathrm{s}^{2}$ (Gravitational constant)] Subject was made to sit with their dominant side elbow flexed at $90^{\circ}$ with mid-pronated forearm resting on a flat horizontal table-surface with the open hand at the edge of the surface. Ruler was suspended vertically by the examiner such that $5 \mathrm{~cm}$ graduation of the ruler was aligned between the web space (space between the thumb and index finger) of the subject's hand. Then he/she was asked to catch the ruler once it is released from the examiner's hand.

\section{RESULTS}

Among the volunteers of age groups 20-39 years and 40-59 years all patients with poor diabetic control showed significantly high reaction time in comparison to their non-diabetic counterparts (180.66 ms vs $231.11 \mathrm{~ms} ; 197.27 \mathrm{~ms}$ vs $224.44 \mathrm{~ms}$ 
Table 1: Glycated hemoglobin and reaction time in non-diabetics and diabetics ( $n=$ number of subjects)

\begin{tabular}{|c|c|c|c|c|c|}
\hline \multirow[b]{2}{*}{$\begin{array}{l}\text { Age } \\
\text { (years) }\end{array}$} & \multicolumn{2}{|c|}{ Non-diabetic } & \multicolumn{2}{|r|}{ Diabetic } & \multirow{2}{*}{$\begin{array}{c}\text { Level of } \\
\text { Significance }\end{array}$} \\
\hline & $\begin{array}{c}\operatorname{HbA}_{1 c}(\%) \\
(\operatorname{Mean} \pm S D)\end{array}$ & $\begin{array}{c}\text { Gross reaction } \\
\text { time }(\mathrm{ms}) \\
(\text { Mean } \pm S D)\end{array}$ & $\begin{array}{c}\operatorname{HbA}_{1 \mathrm{C}}(\%) \\
(\operatorname{Mean} \pm S D)\end{array}$ & $\begin{array}{c}\text { Gross reaction } \\
\text { time }(\mathrm{ms}) \\
(\mathrm{Mean} \pm \mathrm{SD})\end{array}$ & \\
\hline $20-39$ & $4.36 \pm 0.28$ & $180.66 \pm 20.16(n=15)$ & $10.47 \pm 1.98$ & $231.11 \pm 19.64(\mathrm{n}=9)$ & $\mathrm{p}<0.05$ \\
\hline $40-59$ & $4.56 \pm 0.41$ & $197.27 \pm 29.01(\mathrm{n}=11)$ & $9.63 \pm 1.96$ & $224.44 \pm 20.92(\mathrm{n}=18)$ & $\mathrm{p}<0.05$ \\
\hline $60-79$ & $5.44 \pm 0.32$ & $224.00 \pm 5.47(n=5)$ & $10.90 \pm 2.23$ & $230.90 \pm 20.22(n=11)$ & $p>0.05$ \\
\hline
\end{tabular}

respectively). In age groups of 60-79 years, reaction time was insignificantly more in patients with high $\mathrm{HbA}_{1 \mathrm{C}}$ compared to their non-diabetic counterparts (224.00 ms vs $230.90 \mathrm{~ms}$ ) (Table 1 ).

In comparison to non-diabetics, diabetics with $\mathrm{HbA}_{1 \mathrm{c}}$ $7-9 \%, 9-11 \%, 11-13 \%$ and more than $13 \%$ all showed significantly higher reaction time (193.54 ms vs 219.00 ms; $193.54 \mathrm{~ms}$ vs $225.83 \mathrm{~ms} ; 193.54 \mathrm{~ms}$ vs $236.66 \mathrm{~ms}$ vessels, and neurons. Micro-vascular complications give rise to retinopathy and nephropathy, macrovascular ones leads to atherosclerosis due to increased LDL and neuropathy affects both autonomic nervous system and peripheral nervous system. ${ }^{19,20}$ Hyperglycemia is considered as primary cause of vascular complications and is associated with oxidative stress, impaired trace elements and lipid metabolism. ${ }^{21}$ Damage of vasa nervosum,

Table 2: Reaction time in normal and diabetics with gradually increased $\mathrm{HbA}_{1 \mathrm{c}}$ ( $n=$ number of subjects)

\begin{tabular}{|lcccc|} 
Reaction time (ms) & \multicolumn{5}{c}{$\begin{array}{c}\text { Reaction time }(\mathbf{m s}) \\
\text { Normal } \\
\mathbf{( M e a n} \pm \mathbf{S D})\end{array}$} & $\begin{array}{c}\text { Diabetic } \\
\text { (Mean } \pm \text { SD) }\end{array}$ & $\mathbf{H b A}_{1 \mathrm{c}} \mathbf{( \% )}$ & \\
$193.54 \pm 26.77(\mathrm{n}=31)$ & $<5.5$ & $219.00 \pm 19.69(\mathrm{n}=10)$ & $7-9$ & $\mathrm{P}<0.05$ \\
$193.54 \pm 26.77(\mathrm{n}=31)$ & $<5.5$ & $225.83 \pm 19.75(\mathrm{n}=12)$ & $9-11$ & $\mathrm{P}<0.05$ \\
$193.54 \pm 26.77(\mathrm{n}=31)$ & $<5.5$ & $236.66 \pm 18.77(\mathrm{n}=15)$ & $11-13$ & $\mathrm{P}<0.05$ \\
$193.54 \pm 26.77(\mathrm{n}=31)$ & $<5.5$ & More than $250(\mathrm{n}=01)$ & More than 13 & $\mathrm{P}<0.05$ \\
\hline
\end{tabular}

and $193.54 \mathrm{~ms}$ vs more than $250 \mathrm{~ms}$ respectively). Furthermore, a positive Pearson Correlation $(\mathrm{r}=0.4)$ was noted between $\mathrm{HbA}_{1 \mathrm{C}}(\%)$ and reaction time (ms) amongst the patients with poor diabetic control.

\section{DISCUSSION}

Diabetes affects both somatic and autonomic functions. Dysregulation of autonomic function in diabetics were reported by several studies., ${ }^{4,11,12}$ Significant increase in touch threshold ${ }^{13}$ and prolongation of visual and auditory reaction time $^{14}$ was observed in diabetic individuals. Vibrating thresholds were found to be higher in aged diabetics. ${ }^{15}$ Older people with diabetes faced problems with stability and related sensori-motor factors leading them to increased risk of falls. ${ }^{2,16}$ Significant differences in heart rate variability and quantitative sensory testing between diabetic patients and healthy control subjects were noted. ${ }^{17}$ Following a local heat stimulus of $45^{\circ} \mathrm{C}$ applied for $5 \mathrm{~min}$, vasodilatation induced by local heating were severely impaired in diabetic subjects, compared with healthy control subjects. ${ }^{18}$

Complications of diabetes are mainly due to the pathological changes in micro-vessels, macro- formation and accumulation of sorbitol and fructose in Schwann cells due to prolonged hyperglycemia might disrupt structure and function of peripheral nerves. ${ }^{22-24}$

Previous study denoted pronounced impairment of sensory/motor function of peripheral nervous system in chronic diabetics with $\mathrm{HbA}_{1 \mathrm{c}}>7$ evidenced by increased auditory and visual reaction time compared to diabetics with $\mathrm{HbA}_{1 \mathrm{c}}<7$ and stated that the severity of peripheral neuropathy in type 2 diabetics could be due to elevated $\mathrm{HbA}_{1 \mathrm{c}}{ }^{25}$ Present study also noted same type of result. When plasma glucose is episodically elevated over time, small amount of hemoglobin are non-enzymatically glycated to form $\mathrm{HbA}_{1 \mathrm{c}}{ }^{26}$ Normally, the level of $\mathrm{HbA}_{1 \mathrm{C}}$ is less than 5.5\%; 7\% means adequate control and $9 \%$ means very poor control in diabetics. Nonenzymatic addition of any sugar to a protein is called glycation. When once attached, glucose is not released from hemoglobin. Therefore, it remains inside the erythrocyte, throughout the life-span of RBCs (120 days).

As mentioned earlier, neuropathy developed due to prolonged poorly controlled diabetes mellitus altered 
visual reaction time. ${ }^{14}$ Diabetes induced optic nerve diseases, might be one of the causes of alteration in visual reaction time. ${ }^{27}$ Ruler drop method test which can be performed even among the very young individuals, ${ }^{28}$ might be considered as a simple patient-friendly, non-invasive bed side test to assess deficit in reflex activity in a diabetic person with a high $\mathrm{HbA}_{1 \mathrm{C}}$ titer.

\section{ACKNOWLEDGEMENT}

Authors are thankful to Mr. Prem Prasad Panta for statistical help and to Prof. Dr. Shiba Kumar Rai for critical comments on manuscript. This study received NMC-Research Grant for the year 2015 (13072/073).

\section{REFERENCES}

1. Issa CM. Vitamin D and type 2 diabetes mellitus. Adv Exp Med Biol 2017; 996: 193-205.

2. Gu Y, Dennis SM. Are falls prevention programmes effective at reducing the risk factors for falls in people with type 2 diabetes mellitus and peripheral neuropathy: A systemic review with narrative synthesis. J Diabetes Complications 2017; 31: 50416.

3. Karki DB, Yadav SK, Pant S Thusa N, Dangol E, Ghimire S. Prevalence of sensory neuropathy in type 2 diabetes mellitus and its correlation with duration of disease. Kathmandu Univ Med J 2016; 14: 120-4.

4. Tahrani AA, Altaf QA, Piya MK, Barnett AH. Peripheral and autonomic neuropathy in south Asians and white Caucasians with type II diabetes mellitus: Possible explanations for epidemiological differences. J Diabetes Res 2017; 7: 1273789. doi: 10.1155/2017/1273789.

5. Palumbo PJ, Elveback LR, Whisnant JP. Neurologic complications of diabetes mellitus: transient ischemic attack, stroke, and peripheral neuropathy. Adv Neurol 1978; 19: 593-601.

6. Sanchez-Marin FJ, Padila-Medina JA. Simple reaction times and performance in the defection of visual stimuli of patients with diabetes. Comput Bio Med 2010; 40: 591-6.

7. IDF (International Diabetes Federation). Global guidelines for type 2 diabetes 2012, Clinical guidelines task force 14 .

8. Powers AC. Diabetes Mellitus. In Longo DL, Fauci AS, Kasper DL, Hauser SL, Jameson JL, Loscalzo J, editors. Harrison's Principles of Internal Medicine (18 ${ }^{\text {th }}$ ed.). New York: Mc Graw Hill 2012: 2991-2.

9. Mahajan BK. Methods in biostatics for medical students and research workers. $5^{\text {th }}$ ed. New Delhi: Jaypee brothers medical publishers 1989; 141-6.

10. Aranha VP, Joshi R, Samuel AJ, Sharma K. Catch the moving ruler and estimate reaction time in children. Indian J Med Health Sci 2015; 2: 23-26.

11. Fagius J, Wallin BG. Sympathetic reflex latencies and conduction velocities in normal man. J Neurol Sci 1980; 47: 433-48.

12. Abraham RR, Abraham RM, Wynn V. Autonomic and electrophysiological studies in patients with signs or symptoms of diabetic neuropathy. Electroencephalogr Clin Neurophysiol 1986; 63: 22330.

13. McBride MR, Mistretta CM. Light touch thresholds in diabetic patients. Diabetes Care 1982; 5: 311-5.
14. Mohan M, Thombre DP, Das AK, Subramanian $\mathrm{N}$, Chandrashekhar S. Reaction time in clinical diabetes mellitus. Indian J Physiol Pharmacol 1984; 28: 311-4.

15. Maser RE, Laudadio C, DeCherney GS. The effects of age and diabetes mellitus on nerve function. $J$ Am Geriatr Soc 1993; 41: 1202-4.

16. Lord SR, Caplan GA, Colagiuri R, Colagiuri S, Ward JA. Sensori-motor function in older persons with diabetes. Diabet Med 1993; 10: 614-8.

17. Kramer HH, Rolke R, Bickel A, Birklein F. Thermal thresholds predict painfulness of diabetic neuropathies. Diabetes Care 2004; 27: 2386-91.

18. Stansberry KB, Hill MA, Shapiro SA, McNitt PM, Bhatt BA, Vinik AL. Impairment of peripheral blood flow response in diabetes resembles an enhanced aging effect. Diabetes Care 1997; 20: 1711-6.

19. Teliti M, Cogni G, Sacchi L et al. Risk factors for the development of micro-vascular complications of type 2 diabetes in a single-center cohort of patients. Diab Vasc Dis Res 2018; 15: 424-32.

20. Koeppen BM, Stanton BA. Berne and Levy Physiology, $6^{\text {th }}$ ed. Canada: Mosby Elsevier; 2010.

21. Abou-seif MA, Youssef AA. Evaluation of some biochemical changes in diabetic patients. Clin Chim Acta 2004; 346: 161-70.

22. Kumar P and Clark M. Kumar and Clark Clinical Medicine, $5^{\text {th }}$ ed. Edinburgh: WB Saunders; 2002.

23. Atkinson MA, Eisenbarth GS. Type I diabetes: new perspectives on disease pathogenesis and treatment. Lancet 2001; 358: 221-9.

24. Ward JD. Diabetic neuropathy in type II diabetes. Diabetologia 1996; 39: 1676-8.

25. Sembian U, Babitha NE. Study of auditory, visual, reaction time and glycemic control $\left(\mathrm{HbA}_{1 \mathrm{c}}\right)$ in chronic type II diabetes mellitus. J Clin Diagn Res 2014; 8: 11-3.

26. Preston RR, Wilson TE. Lippincott's Illustrated Reviews: Physiology. New Delhi: Wolters Kluwer (India) Pvt. Ltd.; 2013.

27. Veselinovic D, Jovanovic M. Diabetes Mellitus and optic nerve diseases. Acta Fac Med Naiss 2005; 22: 145-8.

28. Aranha VP, Saxena S, Maitra M, Narkeesh K, Arumugam N, Samuel AJ. Reaction time norms as measured by ruler drop method in school-going South Asian children: A cross-sectional study. Homo 2017; 68: 63-8. 